\title{
Family Business Formalization in South Eastern Nigeria: The Role of Intra-Industry Network
}

\author{
Kenneth Chukwujioke Agbim ${ }^{1}$ \\ ${ }^{1}$ Business Administration Department, University of Agriculture, Makurdi, Nigeria \\ Correspondence: Kenneth Chukwujioke Agbim, Business Administration Department, University of Agriculture, \\ Makurdi, Nigeria, E-mail: kennethagbim2012@gmail.com
}

Received: June 8, 2018

Accepted: June 17, 2018

Online Published: July 24, 2018

\begin{abstract}
In most developing countries, majority of the family businesses are started with the support of networks on a small scale in the informal sector because the families and entrepreneurs are poor. Moreover, in areas where they are actively involved in networks, the benefits of such network relationships are rarely harnessed. In South Eastern Nigeria, the state of informality among family businesses has become a source of worry to both the State governments and owner-managers of family businesses. This is coming on the heels of the country's economic recession and the need for the governments to increase their internally generated revenue. And the quest by the family business owner-managers to evade tax so as to increase their income. This is evident from the increasing number of family businesses that are operating outside government system of regulation in the zone. Based on these scenarios this study seeks to assess the effect of intra-industry network on family business formalization in South Eastern Nigeria. Survey design was adopted for the study. The study data were generated through questionnaire and analyzed using linear regression. The results show that intra-industry network significantly and positively affect family business formalization. The researcher recommends encouraging family business owner-managers to be interconnected with other founder/CEOs or descendant/CEOs and family firm employees within the same industry for the mutual benefit of acquiring and sharing information and knowledge that will facilitate the formalization process of their family businesses.
\end{abstract}

Keywords: Family business, Family business formalization, Intra-industry network, South Eastern Nigeria.

\section{Introduction}

The oldest and most dominant type of business in the world is family business (Abouzaid, 2008; European Family Business, 2012). Families establish family businesses to create opportunities for their children, perpetuate family inheritance, hold the family together, give the families financial independence and inheritance (Ayranci, 2010). Family businesses are generally affected by resource constraint. Abou-Moghli and Al Muala (2012) asserts that entrepreneurs access both tangible and intangible resources through networking. Networks are known to provide information, technologies, access to markets and other complementary resources for family businesses (Conner, 2007). However, in spite of the resource constraint, family businesses are still sources of employment 
opportunities, tax revenues to the government, business competition, innovation, creativity, foreign exchange, savings and gross domestic product (Onuoha, 2012). These contributions of family business have been linked to their networking activities.

The network approach to the study of entrepreneurship which was introduced by Aldrich and Zimmer in 1986 emphasize that although entrepreneurs may possess some ideas and skills, they further need resources from their external environment to enable them start-up and continue to pursue the development of their businesses (Abou-Moghli \& Al Muala, 2012). However, in most developing countries where almost all the businesses are family-owned, the family entrepreneurs start these businesses in a small scale in the informal sector because they are poor. Moreover, in areas where they are actively involved in networks, the benefits of such network relationships are rarely harnessed. Corroborating this assertion, Nelson and De Bruijn (2005) opine that informality flourishes because it offers opportunities of economic necessity to the poor, most of who will never be able to assimilate the costs of formalization, and partly because it offers others a low cost arena for experimentation that can lead to business growth.

Business is one aspect of the occupations for which the people of South Eastern Nigeria are famous throughout the country and beyond (Anagbogu, 2008). These peoples' greatest propensity for entrance into family entrepreneurship and exceptional performance has been traced to their renowned zeal, tenacity and positive attitude in business (Onuoha, 2013; Ottih, 2014). In addition, they are energetic, collectivist (appreciates family achievement), particularist (attaches great importance to family relationship), courageous, hospitable, entrepreneurial, live a communal life and belief in the brotherhood of all men. These characteristics have helped them to establish business enterprises all over the country and beyond. However, today, many of the existing family businesses in South Eastern Nigeria are operating outside government system of regulation. A good example is the increasing number of unregistered family businesses in this area.

The state of informality among family businesses in the South Eastern Nigeria has become a source of worry to both the State governments and owner-managers of family business. This is coming on the heels of the country's economic recession and the need for the governments to increase her internally generated revenue. And the quest by the family business owner-managers to evade tax so as to increase their income. Based on these scenarios this study seeks to assess the effect of intra-industry network on family business formalization in South Eastern Nigeria. This study is significant as the outcome will spur government policy makers to formulate workable policies and programs that are geared toward encouraging family businesses to formalize their operations. Also, the result will motivate family business owner-managers to formalize their businesses so as to access the benefits of formalization.

\section{Literature Review}

\subsection{Family Business}

Family business is an emerging aspect of entrepreneurship (Ramona, Hoy, Poutziouris \& Steier, 2008) that is made up of the family (nuclear and extended) and business systems (Gersick, Davis, McCollom, Hampton \& Lansberg, 2007). The family system is internally oriented. Thus, it focuses more on family and social agenda. This includes maintaining balance within the family by minimizing or repressing family conflict (Westhead, Wright \& McElwee, 2011). The business system focuses more on business agenda such as tasks achievement (Warnar, 2012). Family business can be established either through solo or family efforts. When a family business is established through solo, single or lone effort, it is called a single owner family business. Family businesses established through the joint efforts of two or more members of a family are referred to as a family owner business. The family of the single owner holds significant stakes in the family firm. In family owner businesses, the two or more family-related individuals hold significant stakes in the same firm (Miller, Le Breton-Miller \& 
Lester, 2011). Family businesses range from small to large corporations. However, most of them are Small and Medium Enterprises (SMEs).

Family business is "a small, medium-sized, large or multinational enterprise established or bought over through a solo or family (two or more individuals related by blood or marriage) entrepreneurial efforts and operated based on a high level of trust, commitment, familiness, involvement and control by the owning family and a somewhat fused ownership, management and/or governance systems with the founder, descendant or external CEO directing the achievement of the developmental and trans-generational visions of the family business" (Agbim, 2018: 5).

\subsection{Intra-industry Network}

Network is a set of actors that are connected by a set of ties. These ties (i.e., vertices) can be directed (potentially one-directional i.e., giving advice to someone), undirected (physically proximate), dichotomous (present or absent i.e., whether two persons are friends or not) or valued (measured on a scale i.e., strength of friendship) (Borgatti \& Foster, 2003). These ties can be weak or strong. The ties among family members are strong. Strong ties are reliable, but do not offer useful information like weak ties, while weak ties act as "bridges" to information sources not necessarily contained within an entrepreneur's strong tie (Hamid, 2013). The actors, often called "nodes" can be roles, individual person, teams, organizations, industries or even nation states. Their ties may be based on conversation, affection, friendship, kinship, authority, economic exchange or information exchange (Borgatti \& Foster, 2003; Sirec \& Bradac, 2009).

Networks provide entrepreneurs with support, exchanges and resources (tangible and intangible) that constitute strategic tools with which they pursue business development (Seerat, Ali \& Arif, 2011; Abou-Moghli \& Al Muala, 2012). Before the advent of the internet and social media, actors in a network interact through face-to-face contact. The emergence of the internet and social media as communication channel and its use as networking platforms such as Facebook have revolutionalized virtual communication and networking among actors. One of the frequently utilized networks by small and medium scale enterprises is intra-industry network. Intra-industry network is the tie or connection a firm has with other firms within the focal firm's industry. Coleman (1988, as cited in Bellavitis, Filatotchev \& Kamurimo, 2014) asserts that intra-industry network provide cohesive environment, general behavioural rules, low risk and coordination costs, industry legitimacy, and reduced uncertainty regarding the firm's product or service quality (Stam \& Elfringe, 2008; Bellavitis et al., 2014).

\subsection{Family Business Formalization}

Informal organizations are firms that are not registered with the relevant government agencies; firms that operate outside government system of regulation (Nelson \& De Bruijn, 2005). Williams and Nadin (2012) opine that informal entrepreneurships or organizations are the firms that participate in monetary transactions not declared to the State (government or its agency) for tax and/or benefit purposes when they should be declared but which are legal in all other respects. Many entrepreneurs carry on their businesses wholly or partially (Williams, 2006) in the large and growing informal sector all over the world (Charmes, 2009).

There are four types of informal entrepreneurs in the informal entrepreneurship literature (Williams \& Nadin, 2014).

I.Permanent wholly informal entrepreneurs: operate unregistered enterprises wholly in the informal economy with no intention of formalizing in the foreseeable future.

- Temporarily wholly informal entrepreneurs: operate unregistered enterprises wholly informally but with an intention to formalize.

- Permanent partially informal entrepreneurs: operate registered business and paying tax but not declaring 
a proportion of their income and with no intention of increasing the share they declare.

- Temporary partially informal entrepreneurs: operate registered business that do not declare a proportion of their income but who are in transition to formalization.

- Williams and Nadin (2012) identified four potential options for tackling informal entrepreneurship.

- Laissez-faire: to do nothing about informal entrepreneurship; allow informal entrepreneurship to continue the way it is. This option leaves intact the existing negative consequences on formal businesses (e.g., unfair competition), informal businesses (e.g., the inability to gain access to credit for expansion), customers (e.g., no guarantee that health and safety standards have been followed) and governments (e.g., taxes owed are not collected).

- Eradication: repressing rather than nurturing the informal entrepreneurship.

- De-regulation: leveling down rather than leveling up the working conditions.

- Facilitating formalization: Williams and Nadin (2012) concludes that laissez-faire, eradication and de-regulation are unacceptable. The only viable option and dominant public policy approach in recent years is facilitating formalization. Different types of policy measures or variegated approach toward facilitating formalization are required to tackle the different rationales for operating informal enterprises.

Formal organizations are firms that are registered with the government and whose operations are regulated by the government through its relevant agencies. Formalization therefore implies graduating from the informal to the formal sector through a change of form and orientation. Formalization becomes a rational course of action only when the formalized enterprise starts experiencing increased transaction and enhanced growth (Nelson \& De Bruijn, 2005). Formalization can be voluntary or involuntary. Voluntary formalization means graduating from the informal to the formal sector willingly without pressure from the relevant government enforcement agencies. Involuntary formalization is the abandonment of the informal sector (without conscious thought) to comply with the relevant laws governing the formal position as a result of coercion or compulsion from relevant government enforcement agencies. Nelson and De Bruijn notes that a highly formalized position is one in which the enterprise is established as a separate legal entity from the entrepreneur. Highly formalized enterprises are governed by the internal rules and systems, markets and formal business community rules and practices, and the terms of formalization transaction (i.e., regulation, protection of employees, consumers, the environment and the contractual parties). Highly formalized firms benefit from the legitimacy and rights of legal status.

The application of the policy measure for facilitating formalization has attached costs and benefits. The costs of formalization include the time and money spent to comply with regulations concerning business start-up (e.g., registration, licensing) and the operation of a business (e.g., taxes, social security contributions). The benefits of formalization include less harassment by tax collectors and inspectors, little or no fines to pay, access to the services of law enforcement agencies and the court for the purpose of enforcing ones contractual rights, enhanced growth and improved visibility to the public and the requisite authorities (Krause, Ackermann, Gayoso, Hirtbach, Koppa \& Bretas, 2010). Family business formalization therefore is the voluntary or involuntary transitioning of a family business from the informal to the formal sector through a change of form and orientation.

\subsection{Effect of Intra-Industry Network on Family Business Formalization}

Nelson and De Bruijn (2005) conducted a study to examine the formalization process in Tanzania. The study adopted a case study approach. The study focused on five owner-managers who started informally and how they progressed to the formal sector based on the efforts of the owner-managers and other firms. The study reveals a two steps process of formalization that progressed from informal to semi-formal and then to formal status. Each 
step takes the form of a bureaucratic event that changes the legal status of an enterprise. To each level of legal status there is attached a different package of obligation designed to protect consumers, employees and the environment, and to raise public revenue. The researchers conclude that a policy based on formalization seen as a voluntary transaction between operators and government could focus on mutual benefits and reduce the risk of managing fragile enterprises and livelihoods for little benefits. The result reveals that a good relationship among the founder/CEO or successor, family members and employees enhances formalization.

Cavus and Demir (2011) carried out a study to investigate the relationship between institutionalization factors and corporate entrepreneurship in Turkish family firms. Formalization, autonomy, professionalization, transparency and consistency were adopted as the dimensions of institutionalization. The proxies of corporate entrepreneurship were risk-taking, proactivity and innovativeness. Survey research design and questionnaire technique were adopted for the study. The study data were collected from 244 family firms in the province of Ankara and analyzed using correlation and multiple regression statistical method. The results show that formalization, professionalization, transparency and consistency did not support the proxies of corporate entrepreneurship except autonomy. The researchers conclude that to gain competitive advantage, companies should improve their abilities and structures. Thus, a network relationship of family businesses does not enhance formalization, professionalization, transparency and consistency.

\section{Research Methodology}

Survey design was adopted for the study. The population of the study is 2632 . This is made up of 658 family businesses (i.e., number of founder/CEOs), 1749 upper level male managers and 225 upper level female managers. Included in the population were trading, transportation, construction, fashion designing, printing, publishing, manufacturing, production, furniture/wood works, services, and petroleum products marketing family businesses in Abia, Anambra, Ebonyi, Enugu and Imo States. The Table of Random Numbers was employed as a simple random sampling method to select from each State the family businesses to be studied. To select these family businesses, the list of registered businesses with the respective States Ministries of Commerce and Industry were screened based on predetermined criteria. The criteria are that: (i) one or more of the founder/CEO's family member work in the business; (ii) the business was established between 1970 and 2017; (iii) the business is not moribund; (iv) the business is located in the founder's state of origin or residence; and (v) the business has not less than 5 but not more than 200 staff.

The sample size of 335 was computed using Krejcie and Morgan (1970) sample size formula for finite population. The proportion of the sample size for each stratum were computed using Bowley (1937) proportional allocation formula. The sample size of 335 is made up of 84 family businesses (i.e., number of founders/CEOs), 222 upper level male managers and 29 upper level female managers. The variables in the study questionnaire are measured on a 5-point Likert scale that ranged from strongly agree (5) to strongly disagree (1). The study questionnaire was validated by two management experts. The validity of the questionnaire was reconfirmed using Bartlett's test of Sphericity and Kaiser-Meyer-Olkin (KMO) measure of sampling adequacy. The results show that the Bartlett's test was significant $(1598.794$, Sig. $=0.00)$, while the KMO $(0.746)$ is above 0.70 as recommended by Neuman (2006). The reliability of the questionnaire was confirmed by the overall Cronbach's alpha value of 0.793 .

\subsection{Model Specification}

The general model for this study is given as:

$\mathrm{FBF}=f(\mathrm{IIK})$

Where

FBF $\quad=\quad$ family business formalization 


$$
\text { IIK = intra-industry network }
$$

The general linear regression model is given as:

$$
\mathrm{Y}=\beta_{0}+\beta_{1} \mathrm{X}+\mathrm{e}
$$

Where

$\begin{array}{lll}\mathrm{Y} & = & \text { estimated value of the dependent variable } \\ \beta_{0} & = & \text { the intercept of the line with } \mathrm{Y}-\text { axis } \\ \beta_{1} & = & \text { the slope. It estimates the rate of change in Y for a unit change in } \mathrm{X} \\ \mathrm{X} & = & \text { independent variable } \\ \mathrm{e} & = & \text { random error }\end{array}$

The effect of intra-industry network on family business formalization was tested using the model in equation (iii). The apriori expectation is that intra-industry network will positively affect family business formalization, while the absence of family business involvement in intra-industry network is expected to negatively affect family business formalization.

FBF

$$
=\quad \beta_{0}+\beta_{1} \mathrm{IIK}+\mathrm{e}
$$

Where

$\begin{array}{ccc}\mathrm{FBF} & = & \text { family business formalization } \\ \beta_{0} & = & \text { the intercept of the line with } \mathrm{Y} \text { - axis } \\ \beta_{1} & = & \text { the slope. It estimates the rate of change in Y for a unit change in } \mathrm{X} \\ \mathrm{IIK} & = & \text { intra-industry network } \\ \mathrm{e} & = & \text { random error }\end{array}$

The researcher administered the questionnaire on the respondents from 84 small and medium-sized family businesses with the help of five research assistants. The research hypothesis was tested using simple regression with the aid of SPSS (Version 21.0 for Windows). The decision rule is to reject the null hypothesis if the p-value is less than or equal to $5 \%$. Otherwise the null hypothesis is not rejected.

\begin{tabular}{|c|c|c|c|c|c|c|c|c|c|c|}
\hline \multirow{2}{*}{$\begin{array}{l}\text { Degree of } \\
\text { Response }\end{array}$} & \multicolumn{2}{|c|}{ QIS1 } & \multicolumn{2}{|c|}{ QIS2 } & \multicolumn{2}{|c|}{ QIS3 } & \multicolumn{2}{|c|}{ QIS4 } & \multicolumn{2}{|l|}{ Total } \\
\hline & $\mathbf{F}$ & $\%$ & $\mathbf{F}$ & $\%$ & $\mathbf{F}$ & $\%$ & $\mathbf{F}$ & $\%$ & $\mathbf{F}$ & $\%$ \\
\hline SA & 154 & 48.13 & 133 & 41.56 & 151 & 47.19 & 94 & 29.38 & 532 & 41.56 \\
\hline A & 95 & 29.69 & 87 & 27.19 & 85 & 26.56 & 139 & 43.44 & 406 & 31.72 \\
\hline $\mathrm{U}$ & 17 & 5.31 & 33 & 10.31 & 4 & 1.25 & 26 & 8.12 & 80 & 6.25 \\
\hline $\mathrm{D}$ & 41 & 12.81 & 49 & 15.31 & 53 & 16.56 & 37 & 11.56 & 180 & 14.06 \\
\hline SD & 13 & 4.06 & 18 & 5.63 & 27 & 8.44 & 24 & 7.50 & 82 & 6.41 \\
\hline Total & 320 & 100.0 & 320 & 100.0 & 320 & 100.0 & 320 & 100.0 & 1280 & 100.0 \\
\hline Mean & 4.18 & & 3.84 & & 3.88 & & 3.76 & & 3.88 & \\
\hline$S$ & 1.97 & & 1.84 & & 1.86 & & 1.79 & & 1.86 & \\
\hline
\end{tabular}

4. Summary of the Analysis of the Coded Responses to the Questionnaire Item Statements

Table 1.Analysis of the Coded Responses to Questionnaire Item Statements

Note: QIS = Questionnaire Item Statement, F = Frequency, SA = Strongly Agree, A = Agree, $\mathrm{U}=$ Undecided, $\mathrm{D}=$ disagree, $\mathrm{SD}=$ Strongly Disagree, $\mathrm{S}=$ Standard Deviation Source: Author's Computation, 2017 
Table 1 shows that $77.82 \%$ (249) of the respondents affirm the first questionnaire item statement in Appendix I. The responses show an aggregate mean value of 4.18 which is higher than the threshold of 3.0. Based on this statistics it can be inferred that family businesses which enjoy cohesive environment are registered with the relevant government agencies. The analysis of the responses generated from the second questionnaire item statement show that $68.75 \%$ (220) of the respondents confirm the statement. The responses further show an aggregate mean value (3.84) that is higher than the threshold of 3.0. It can therefore be deduced from the statistics that the same government laws and market/community rules regulates both the operations of the business and the behaviour of the stakeholders.

The analysis of the responses to the third questionnaire item statement in Table 1 reveals that 73.75\% (236) of the respondents confirm the statement. The responses also show an aggregate mean value of 3.88 which is higher than the threshold of 3.0. The statistics therefore imply that when family businesses are regulated, their business operations are then carried on in such a way that the employees, consumers, the environment and contractual parties in the industry are protected at low risk and cost. Furthermore, the analysis of the responses to the fourth questionnaire item statement shows that $72.82 \%$ (233) of the respondents affirm the statement. The responses also show an aggregate mean value (3.76) which is higher than the threshold of 3.0. It can therefore be deduced that regulated family businesses experience increased transaction, enhanced growth, increased taxes to the government and reduced environmental uncertainty in the industry. Overall, the aggregate affirmation to all the questionnaire item statements by $73.28 \%$ of the respondents and the overall aggregate mean value of 3.88 depicts that intra-industry network affects family business formalization.

\section{Test of Hypothesis}

$\mathrm{H}_{0}$ : Intra-industry network has no significant and positive effect on family business formalization.

$\mathrm{H}_{\mathrm{a}}$ : Intra-industry network has significant and positive effect on family business formalization.

The results of the goodness-of-fit and the significance of the regression of family business formalization on intra-industry network are presented in Tables 2(a) and 2(b).

Table 2(a): Goodness-of-fit of the Regression of Family Business Formalization on Intra-industry Network

\begin{tabular}{lllllll}
\hline Model & $\mathbf{R}$ & R Square & $\begin{array}{l}\text { Adjusted } \\
\text { Square }\end{array}$ & $\begin{array}{l}\mathbf{R} \\
\text { Std. Error of the } \\
\text { Estimate }\end{array}$ & Durbin-Watson \\
\hline 1 & .820 & .672 & .695 & .435 & 2.000 \\
\hline
\end{tabular}

Predictors: (Constant), Intra-industry network

Dependent Variable: Family business formalization

Source: Author's Computation, 2017

Table 2(b): Significance of the Regression of Family Business Formalization on Intra-Industry Network

\begin{tabular}{|c|c|c|c|c|c|c|c|}
\hline & $\begin{array}{l}\text { Stand } \\
\text { Coeffi }\end{array}$ & ized & $\begin{array}{l}\text { Standardized } \\
\text { Coefficients }\end{array}$ & & & $\begin{array}{l}\text { Collinearity } \\
\text { Statistics }\end{array}$ & \\
\hline Model & B & $\begin{array}{l}\text { Std. } \\
\text { Error }\end{array}$ & Beta & $\mathbf{T}$ & Sig. & Tolerance & VIF \\
\hline 1(Constant) & 3.324 & .283 & & 11.746 & .000 & & \\
\hline $\begin{array}{l}\text { Intra-industry } \\
\text { network }\end{array}$ & .275 & .086 & .291 & 3.198 & .000 & 1.000 & 1.000 \\
\hline
\end{tabular}

Predictors: (Constant), Intra-industry network

Dependent Variable: Family business formalization

Source: Author's Computation, 2017 
The result of the goodness-of-fit of the regression of family business formalization on intra-industry network in Table 2(a) show that a strong relationship exists between intra-industry network and family business formalization $(\mathrm{R}=.820)$. This suggests that intra-industry network can significantly influence family business formalization. The coefficient of determination $\left(\mathrm{R}^{2}\right)$ of .672 shows that intra-industry network makes a significant contribution to family business formalization. The adjusted $\mathrm{R}^{2}$ show that intra-industry network explain $69.5 \%$ of the total variance in family business formalization (Adj. $\mathrm{R}^{2}=.695$ ), while the standard error of .435 show that intra-industry network is significant in explaining the variation in family business formalization. This implies that intra-industry network helps members of a family to achieve family business formalization. The Durbin-Watson statistics value of 2.000 depicts that there is no autocorrelation in the errors of the regression model. Therefore, the predictor is truly significant. The collinearity statistics in Table 2(b) shows the tolerance value of 1.000 and a VIF value of 1.000 . Since the tolerance value is higher than .40 and the VIF value is less than 2.500, it implies that the data has no collinearity problem. Table 2 (b) further show that the effect of intra-industry network on family business formalization is significant and positive $(\beta=.291, \mathrm{t}=3.198, \mathrm{P}<.05)$. Therefore, $\mathrm{H}_{0}$ is rejected. In conclusion, intra-industry network has significant and positive effect on family business formalization.

\section{Discussion and Conclusion}

The result of this study is somewhat in tandem with the findings of Nelson and De Bruijn (2005) and inconsistent with that of Cavus and Demir (2011). The similarity between the result of the current study and that of Nelson and De Bruijn can be attributed to the fact that the two studies were conducted in the same geographical setting, Africa. The inconsistency in the result of the current study and the findings of Cavus and Demir can be traced to the differences in the business acumen, values and relationship between family business founder/CEOs in Turkey and Nigeria.

There are many family businesses operating in the growing informal sector in different parts of the world either wholly or partially (Williams, 2006; Charmes, 2009). Although the operations of these businesses are legal, they are not registered and regulated by the government and as such the founder/CEOs do not declare their transactions for tax and/or benefit purposes (Nelson \& De Bruijn, 2005; Williams \& Nadin, 2012, 2014). The informal businesses are many because they are small and easy to establish as there are no stringent rules to be followed. However, they tend to start formalizing owing to the facilitation effort of the government through its relevant agencies (Williams \& Nadin, 2012) and the influences from the network tie in the focal firm's industry (Stam \& Elfringe, 2008; Bellavitis et al., 2014). Highly formalized businesses are governed by the internal rules and systems, market and formal business community rules and practices, and the terms of formalization transaction (i.e., regulation, protection of employees, consumers, the environment and the contractual parties) (Nelson \& De Bruijn, 2005). Such formalization efforts are associated with some costs. The costs of formalization include the time and money spent to register, comply with business regulation and operate the business (e.g., taxes, social security contributions). The benefits of formalization include less harassment by tax collectors and inspectors, little or no fines to pay, access to the services of law enforcement agencies and the court for the purpose of enforcing contractual rights, enhanced growth and improved visibility to the public and the requisite authorities (Krause et al., 2010).

For a family business to be influenced by intra-industry network, the founder/CEO or descendant/CEO and employees of the business should be actively involved in relationships that encourages and facilitates resource acquisition and sharing. Involvement in network relationship has become more important now than ever before owing to the increase in governments' revenue drive and the benefits of family business formalization. Consequently, family business founder/CEOs or descendant/CEOs and family firm employees should be encouraged to be interconnected with other founder/CEOs or descendant/CEOs and family firm employees within 
the same industry for the mutual benefit of acquiring and sharing information and knowledge that will facilitate the formalization process of their family businesses.

The outcome of this study has further extended the scope of knowledge of family business. This is in the light that it has shown the benefits of formalization to family businesses and the government. Moreover, the result stands as a positive recommendation to family business founder/CEOs or descendant/CEOs and the government. To family businesses, the study brings to the fore the importance of formalizing through the support of intra-industry network. To the government, the study recommends the best strategy to adopt during formalization and the inherent benefits. The limitation of this study is associated with its focus on only one type of network and on small and medium sized family businesses. This limitation will definitely affect the generalization of result for other network types and other sizes and types of businesses. Thus, further studies in this area can focus on other network types like inter-industry, business and social networks. Similar studies can as well select respondents from non-family, micro and large businesses.

\section{References}

Abou-Moghli, A. \& Al Muala, A. (2012). Impact of entrepreneurial networks in the success of business on-going stage in Jordanian manufacturing companies. American Academic \& Scholarly Research Journal, 4(2), $1-9$.

Abouzaid, S. (2008). IFC family business governance handbook. Retrieved form http://www.ifc.org/wps/wcm/connect/15c9c0048582f6883f9ebfco46daa89/FB_English_final_200 8.pdf?Mod=AJPERES on October 21, 2016.

Agbim, K. C. (2018). Business network effect on the institutionalization of family businesses in South Eastern Nigeria. Open Journal of Economics and Commerce, 1(1), 1-10.

Anagbogu, I. (2008). Igbo business in Nigeria. Awka: Sellyoak.

Ayranci, E. (2010). Family involvement in and institutionalization of family business: A research. Business and Economic Horizons, 3(3), 83-104.

Bellavitis, C., Filatotchev, I. \& Kamuriwo, D. S. (2014). The effects of intra-industry and extra-industry networks on performance: A case of venture capital portfolio firms. Managerial and Decision Economics, 35(2), 129-144. doi: 10.1002/mde.2647

Borgatti, S. P. \& Foster, P. C. (2003). The network paradigm in organizational research. Journal of Management, 29(6), 991-1013.

Bowley, A. L. (1937). Elements of statistics. London: P. S. Kings and Staples

Cavus, M. F. \& Demir, Y. (2011). Institutionalization and corporate entrepreneurship in family firms. African Journal of Business Management, 5(2), 416-422. doi:10.5897/AJBM10.500

Charmes, J. (2009). Concepts, measurement and trends, In J. P. Jutting \& J. R. Laiglessia (Eds.), Is informal normal? Towards more and better jobs in developing countries (Pp19-35). Paris: OECD.

Conner, T. (2007). Research notes and commentaries, market orientation and performance. Strategic Management Journal, 28, 957-959.

European Family Business (2012, June). Family business. Retrieved from http:/www.europeanfamilybusiness.eu/uploads/modules/publications/family-business-statistics.pdf on March 21, 2016.

Gersick, K. E., Davis, J. A., McCollom, M., Hampton, M. \& Lansberg, I. (2007). Generation to generation - life cycles of the family business. Boston: Harvard Bsuiness School Press.

Hamid, N. F. B. A. (2013). Family business culture, entrepreneurial orientation and the new economic policy 
on family business survival: A study between the Malays and Chinese of micro and small-sized family business in Malaysia (Unpublished Ph.d thesis). The University of York, York.

Krause, M., Ackermann, M., Gayoso, L., Hirtbach, C., Koppa, M. \& Bretas, L. S. (2010). Formalization and business development in Mozambique: How important are regulations? gGmbH: German Development Institute.

Krejcie, R. V. \& Morgan, D. W. (1970). Determining sample size for research activities. Educational and Psychological Measurement, 30, 607-610.

Miller, D., Le Breton-Miller, I. \& Lester, R. H. (2011). Family and lone founder ownership and strategic behaviour: Social context, identity and institutional logics. Journal of Management Studies, 48(1), 1-25.

Nelson, E. \& De Bruijn, E. (2005). The voluntary formalisation of enterprises in a developing economy: The case of Tanzania. Journal of International Development, 17(4), 575-593.

Neuman, L. (2006). Social research methods: Qualitative and quantitative approaches. London: Pearson International.

Onuoha, B. C. (2012). Professionalizing family business in the South-East Region of Nigeria. International Business and Management, 5(1), 153-161. doi:10.3968/j.ibm.1923 842820120501.1075

Onuoha, B.C. (2013). Challenges and problems of professionalizing family businesses in South-East, Nigeria. American International Journal of Contemporary Research, 3(4), 130-139.

Ottih, L. O. (2014). Entrepreneurship: Personality, process and enterprise. Port Harcourt: Pearl.

Ramona, K. Z., Hoy, F., Poutziouris, P. Z. \& Steier, L. P (2008). Emerging paths of family entrepreneurship research. Journal of Small Business Management, 46(3), 317-330.

Seerat, F., Ali, M. \& Arif, S. (2011). Network classification on the basic of functions they perform and its relationship with internationalization process of SMEs in developing countries - Exploratory research on Pakistan. Australian Journal of Business and Management Research, 1 (8), 35-53.

Sirec, K. \& Bradac, B. (2009). How does networking impact the SMEs growth.Organizacija, 42 (2), 59-66. doi: 10.2478/V10051-0051-009-0003-4

Stam, W. \& Elfring, T. (2008). Entrepreneurial orientation and new venture perforformance: The moderating role of intra- and extra industry social capital. Academy of Management Journal, 51(1), 97-111.

Warnar, P. (2012). Family business and knowledge transfer: How to survive to the next generation. Delft University of Technology.

Westhead, P., Wright, M. \& McElwee, G. (2011). Entrepreneurship perspectives and cases. London: Pearson Education.

Williams, C. C. \& Nadin, S. (2012). Tackling entrepreneurship in the informal economy: Evaluating the policy options. Journal of Entrepreneurship and Public Policy, 1(2), 111-124.

Williams, C. C. \& Nadin, S. (2014). Facilitating the formalization of entrepreneurs in the informal economy: Towards a variegated policy approach. Journal of Entrepreneurship and Public Policy, 3(1), 33-48.

Williams, C. C. (2006). The hidden enterprise culture: Entrepreneurship in the underground economy. Cheltenham: Edward Elgar.

Appendices

Appendix I: Research Questionnaire

\begin{tabular}{|c|c|c|c|c|c|c|c|}
\hline $\mathbf{S} / \mathbf{N}$ & Item Statement & & SA & $\mathbf{A}$ & $\mathbf{U}$ & $\mathbf{D}$ & SD \\
\hline \multicolumn{8}{|c|}{ Effect of Intra-industry Network on Family } \\
\hline \multicolumn{8}{|c|}{ Business Formalization } \\
\hline 1. & Family businesses that are registered with the & relevant & & & & & \\
\hline
\end{tabular}


government agencies enjoy cohesive environment in the industry.

2. The government laws and the market/community rules which regulate business operations also act as the general behavioural rules in the industry.

3. Regulated family businesses protect employees, consumers, the environment and contractual parties in the industry at low risk and cost.

4. Regulated family businesses experience increased
transaction, enhanced growth, increased taxes to the
government and reduced environmental uncertainty in the
industry.

\section{Copyrights}

Copyright for this article is retained by the author(s), with first publication rights granted to the journal.

This is an open-access article distributed under the terms and conditions of the Creative Commons Attribution license (http://creativecommons.org/licenses/by/4.0/). 